\title{
O vulto da Bahia e o lugar da mulher: Maria Quitéria/Soldado Medeiros no carnaval carioca
}

\section{Resumo:}

Neste artigo, analiso a presença de Maria Quitéria de Jesus/Soldado Medeiros na cultura brasileira a partir de doze sambas-enredos de Escolas de samba do Rio de Janeiro e de seus respectivos desfiles, entre os carnavais de 1954 e 2020. Com base no material encontrado e nas análises realizadas, podemos dizer que há duas narrativas significativamente distintas sobre a personagem. Na primeira, entre as décadas de 50 e 70, há uma perspectiva militarizada, onde a personagem é construída a partir de sua capacidade guerreira e da sua atuação nas lutas de independência; na segunda, entre as décadas de 90 e 10, há uma perspectiva feminista, sendo a personagem construída a partir de sua capacidade de transgredir as normatividades de gênero.

Palavras-chave:

Maria Quitéria, Soldado Medeiros, Carnaval

Resumen:

En este artículo, analizo la presencia de Maria Quitéria de Jesus/Soldado Medeiros en la cultura brasileña a partir de doce sambas-enredos de Escuelas de Samba de Río de Janeiro, y sus respectivos desfiles, entre los carnavales de 1954 y 2020. Basado en el material encontrado y en los análisis realizados, podemos decir que hay dos narrativas significativamente distintas sobre el personaje. En la primera, entre los años $50 \mathrm{y}$ 70, hay una perspectiva militarizada, donde el personaje se construye a partir de su capacidad guerrera y su desempeño en las luchas independentistas; en la segunda, entre las décadas de 90 y 10, hay una perspectiva feminista, y el personaje se construye a partir de su capacidad para transgredir las normas de género.

Palabras-clave:

María Quitéria, Soldado Medeiros, Carnaval 


\author{
Glória à heroína \\ Maria Quitéria \\ Mulher de grande valor \\ Lutou pela liberdade \\ E contra o terrível preconceito
}

(Em cima da hora, 1972)

Maria Quitéria de Jesus, o Soldado Medeiros, nasceu em 1792, na vila de São José das Itapororocas, no interior da Bahia, primogênita de Gonçalo Alves de Almeida e Quitéria Maria de Jesus, e aí viveu até os doze anos. Após a morte da mãe e da primeira madrasta, e com o terceiro casamento do pai, a família se muda para a Serra da Agulha. Em setembro de 1822, aos trinta anos, sob o nome de Soldado Medeiros, assenta praça como soldado, em Cachoeira, no regimento da artilharia, sendo logo depois transferido para infantaria, para o Batalhão dos Periquitos, onde sua habilidade com espingardas seria mais bem aproveitada.

As guerras de independência da Bahia, que visavam expulsar a autoridade portuguesa do estado, onde era mantida uma grande frota militar, aconteceram entre fevereiro de 1822 e julho de 1823. Soldado Medeiros, no entanto, lutou entre setembro de 1822 e julho de 1823 . Nesse curto período, não só foi reconhecido e ascendeu militarmente pela bravura, especialmente pela sua atuação nas batalhas da Pituba, de Itapuã e da Foz do Rio Paraguaçu, como também teve sua transição de gênero descoberta e publicitada. É possível também que nesse período tenha se casado com o furriel João José Luís, mas as informações são escassas e se resumem a uma portaria, de 31 de março de 1823, do Conselho Interino do Governo (Reis Júnior 1953: 48).

Apesar de não sabermos exatamente quando a transição de gênero é conhecida pelos seus companheiros e superiores, sabemos que uma portaria de 28 de março de 1823, do mesmo Conselho, destina "ao cadete Maria Quitéria, dois saiotes de camelão ou de outro pano semelhante" (idem: 47) para que feminizasse o seu uniforme, com a incorporação de um saiote ao estilo escocês, o que significa não só que a transição de gênero se manteve em segredo por no máximo sete meses, mas que também lhe foi autorizado a seguir como Soldado Medeiros, ainda que fosse entendido como uma mulher. Nesse sentido, sendo feminizado o uniforme, a sua manutenção não indica uma transição de gênero, ainda que signifique uma transgressão, uma vez que estava vedada a participação feminina no exército brasileiro.

Após o fim da guerra, recomendada pelo comandante do Batalhão dos Periquitos, embarca em 29 de julho de 1823 para o Rio de Janeiro, onde é recebida como soldado, no dia 20 de agosto, pelo imperador D. Pedro I. O soldado Maria Quitéria é então condecorado com a insígnia de Cavaleiro da Ordem Imperial do Cruzeiro, honraria dada aos heróis do país recém independente, e recebe também uma pensão de alferes em retribuição de seus feitos (idem: 57). Em setembro de 1823, volta à Bahia, onde casa novamente, agora com o lavrador Gabriel Pereira de Brito, com quem tem uma filha, Luísa Maria da Conceição. Entre 1823 e 1843, mora provavelmente em Feira de Santana, onde luta judicialmente pela herança do pai, e entre 1843 
e 1853, em Salvador, viúva, com uma filha (idem: 63-68). Em 21 de agosto de 1853, morre, de inflamação no fígado, em Salvador, com grandes dificuldades financeiras e oculares (idem:70).

No que se refere ao gênero de Maria Quitéria/Soldado Medeiros, a personagem é hegemonicamente narrada de duas formas. Na primeira, ignora-se completamente a transição de gênero, logo é narrada como uma mulher que transgride o papel feminino por participar de uma guerra. Na segunda, a transição de gênero é entendida como um "disfarce", um sacrifício pela pátria, consequentemente é narrada como uma mulher que vai à guerra disfarçada de homem. De uma forma ou de outra, a transição de gênero ou é ignorada ou é entendida exclusivamente como uma transgressão à mulheridade. Não há, portanto, narrativa histórica ou literária, ou mesmo texto crítico, que considere a transição de gênero vivida pela personagem como uma possibilidade de compreensão de si, como aquilo que entendemos hoje como uma identidade. Apesar disso, acreditamos que a transição de gênero vivida por Quitéria/Medeiros pode ser lida e entendida para além de sua insignificância e para além da ideia de "disfarce".

Assim, analisaremos doze sambas-enredos, de Escolas de samba do Rio de Janeiro, que abordam Maria Quitéria/Soldado Medeiros, visando entender principalmente como é narrada a transição de gênero vivida pela personagem. Dialogaremos, no entanto, não só com as letras dos sambas que conseguimos encontrar, mas também com as músicas, as fotos, os vídeos, os cartazes e outros materiais produzidos pelas Escolas e pela imprensa. Os doze sambas-enredo dizem respeito a todos os carnavais encontrados sobre a personagem, sendo o primeiro de 1954 e o último de 2020.

Sobre os materiais encontrados, podemos dizer que obedecem a duas variáveis: o ano do carnaval e a divisão em que a Escola de samba se apresentou. Nesse sentido, encontramos mais material entre as Escolas que desfilaram na primeira e na segunda divisão do carnaval carioca, assim como encontramos mais material entre as Escolas que desfilaram a partir dos anos setenta, o que indica não só que a memória no carnaval é uma preocupação mais recente, mas que está também diretamente ligada ao poderio econômico das Escolas de samba. Afinal, como sabemos, o desfile destas Escolas é uma competição organizada em diversas divisões, cuja finalidade é tanto organizar as apresentações quanto distribuir visibilidade e dinheiro entre as agremiações.

De forma geral, podemos afirmar que apenas as duas primeiras divisões gozam de grande visibilidade, uma vez que aparecem na televisão e desfilam no principal palco do carnaval carioca, atualmente o Sambódromo, enquanto as outras divisões desfilam em palcos relativamente improvisados e com pouca ou nenhuma cobertura midiática. Como explica César Batista da Silva (2007: 47), essa organização em diferentes divisões ocorre desde 1952 e se deve tanto à grande quantidade de Escolas de samba quanto à necessidade de dividir as subvenções públicas. A rotatividade entre os grupos é garantida pelo descenso das últimas colocadas de um grupo mais bem posicionado, e a ascensão das mais bem colocadas de outro grupo de divisão inferior. No carnaval de 1954 tínhamos apenas duas divisões com pouco mais de cinquenta Escolas, enquanto no carnaval de 2020 tínhamos nove divisões com mais de cem Escolas.

Por uma questão metodológica, mas também como forma de organizar este artigo, separa- 
mos os sambas-enredo em dois grandes grupos: os sambas-enredo que estão diretamente centrados na figura de Maria Quitéria/Soldado Medeiros, chamados de sambas-enredo diretos, e os sambas-enredo onde a personagem é um elemento secundário, chamados de sambas-enredo indiretos. Nesse sentido, foram encontrados cinco sambas-enredo com protagonismo do soldado baiano, sendo que todos se apresentaram na segunda e na terceira divisão do carnaval, entre 1954 e 1977, e sete sambas-enredo que abordam secundariamente a personagem, mas que têm como protagonistas ou o Brasil ou a Bahia ou as mulheres brasileiras, sendo que todos se apresentaram na primeira e na segunda divisão do carnaval, entre 1964 e 2020.

Estas informações prévias indicam que há mais de quarenta anos a personagem não é tema principal do carnaval carioca, assim como também indicam que Maria Quitéria/Soldado Medeiros nunca foi protagonista de um carnaval da primeira divisão carioca. Além disso, como mostraremos, a sua história é recorrentemente recuperada a partir da história do Brasil e da Bahia, e mais recentemente há uma releitura feminista da personagem, que passa a narrá-la como exemplo do que pode a mulher (cisgênera).

Por fim, antes de analisarmos os sambas-enredo, é preciso dizer que a história de Maria Quitéria/Soldado Medeiros tem uma longa, apesar de pouco conhecida, tradição literária, cujas primeiras duas obras - o diário de Maria Graham, de 1824, e a epopeia de Ladislau dos Santos Titara, de 1837 - foram publicadas com Maria Quitéria/Soldado Medeiros ainda viva. ${ }^{1}$ Nesse mesmo sentido, há também uma longa tradição cordelista sobre a personagem, além de obras audiovisuais recentes, como o filme Maria Quitéria: Honra e Glória, de 2020.

\section{Maria Quitéria, heroína da independência da Bahia}

A primeira Escola de samba a transformar Maria Quitéria/Soldado Medeiros em samba-enredo foi a Caprichosos de Pilares, em 1954, desfilando na segunda divisão do carnaval carioca, sob o título de Maria Quitéria. A data coincide com uma série de homenagens promovidas pelo governo varguista e pelo exército brasileiro em torno do centenário de morte da "heroína" brasileira. Nesse sentido, junto com a inauguração de sua estátua no Largo da Soledade, em Salvador, pelo governo varguista, com a criação da Medalha Maria Quitéria, pelo exército brasileiro, e com a publicação de três livros biográficos (Alves 1952; Reis Júnior 1953; Carvalho 1958), ${ }^{2}$ sendo dois deles financiados pelo Estado brasileiro, entendemos esse primeiro carnaval da Caprichosos como parte dessas comemorações.

Ainda dentro dessas comemorações está o carnaval da Unidos da Favela, de 1959, que, sob o título Quatro vultos da Bahia, desfilou na segunda divisão do carnaval e homenageou não só Maria Quitéria/Soldado Medeiros, mas também Rui Barbosa, Castro Alves e Marcílio Dias. Este é um fato importante, visto que é a única vez em que a personagem é narrada junto a outras figuras masculinas, afinal, como veremos, quando comparada a outras pessoas, Maria Quitéria/Soldado Medeiros é quase sempre narrada, inclusive literariamente, ${ }^{3}$ junto a figuras femininas.

A Caprichosos de Pilares não é a única Escola de samba, como veremos, a produzir mais de um carnaval em que se aborda a personagem, no entanto, é a única a narrar Maria Quitéria/ Soldado Medeiros como tema principal do carnaval por duas vezes. Ademais, o carnaval da Ca- 
prichosos de 1977, sob o título de Maria Quitéria, heroína de uma raça, que neste ano desfilava na terceira divisão, foi também o último carnaval que teve a personagem como protagonista de um samba-enredo.

Entre os dois carnavais da Caprichosos, Maria Quitéria/Soldado Medeiros aparece, como já dissemos, no samba-enredo da Unidos da Favela, de 1959, e também nos sambas-enredo da Unidos do Viradouro, em 1964, que desfilou na terceira divisão, sob o título Maria Quitéria, e da Unidos de Bangu, em 1969, que desfilou na terceira divisão, sob o título Maria Quitéria, heroína da independência. Assim sendo, podemos dizer que a personagem é um tema mais constante nos palcos improvisados do carnaval carioca, uma vez que a sua presença nos palcos principais, ainda que na segunda divisão, está restrita aos dois carnavais da década de cinquenta.

Nesse mesmo sentido, é preciso apontar que Maria Quitéria/Soldado Medeiros nunca foi tema principal de um samba-enredo da primeira divisão, assim como não há novos carnavais sobre a personagem há mais de quarenta anos. Além disso, podemos dizer que enquanto as outras Escolas de samba alcançaram resultados pífios com os sambas-enredo sobre a personagem, a Caprichosos de Pilares, apesar de nunca ter ganho um carnaval sobre Maria Quitéria/ Soldado Medeiros, conseguiu um segundo lugar em 1954, o que a levou para a primeira divisão, assim como conseguiu um terceiro lugar em 1977, o que a levou para a segunda divisão.

No dia 28 de fevereiro de 1954, domingo de carnaval, a Caprichosos de Pilares inaugura, na Praça XI, na segunda divisão do carnaval carioca, os sambas-enredo sobre Maria Quitéria/ Soldado Medeiros. ${ }^{4}$ Nesse mesmo dia, desfilavam no palco principal do carnaval, na Avenida Presidente Vargas, as Escolas de samba da primeira divisão. Esse desfile concomitante fez com que toda a mídia se voltasse às Escolas que desfilavam na Presidente Vargas, o que explica certamente a escassa cobertura midiática das Escolas da segunda divisão em 1954. Da Escola de Pilares registrou-se apenas três informações: a Escola foi a sétima a desfilar, o samba-enredo era de Geraldo Sargento e a Escola foi a vice-campeã, sendo a Beija-Flor a campeã do carnaval da segunda divisão e a Mangueira da primeira divisão.

Fora isso, nada sabemos sobre aquele que foi o quinto desfile da história da Caprichosos de Pilares, e que levou a Escola pela primeira vez, no ano seguinte, aos palcos principais do carnaval carioca. Apesar de não termos encontrado nem mesmo a letra do samba-enredo, nos arriscamos a dizer que, seguindo as outras comemorações em torno do centenário de morte da personagem, é provável que a narrativa estivesse centrada em sua capacidade guerreira, como ocorria na literatura do período (Maia 2021). No entanto, nada podemos inferir sobre como era narrada, ou não, a sua transição de gênero.

Cinco anos depois, no dia 8 de fevereiro de 1959, domingo de carnaval, Maria Quitéria/ Soldado Medeiros volta à Praça XI, na segunda divisão do carnaval carioca, acompanhada de outros três vultos "baianos", como canta a Escola: o "timoneiro da democracia" Rui Barbosa, o "poeta da escravidão" Castro Alves e o "herói" Marcílio Dias. A Escola foi a décima primeira a desfilar e terminou na última colocação, ${ }^{5}$ naquele que é provavelmente o único desfile da Unidos da Favela. Não encontramos muitas informações sobre o carnaval, mas os jornais publicaram a letra do seu samba-enredo. 
O samba-enredo Quatro vultos da Bahia, de autoria desconhecida, é breve, mas traz informações interessantes sobre Maria Quitéria/Soldado Medeiros. Apesar de nunca citar o nome masculino da personagem histórica, e nem mesmo falar de sua transição de gênero, o samba-enredo, ao compará-lo com outras figuras masculinas, termina por associar, unicamente, características entendidas como masculinas à personagem. Nesse sentido, Maria Quitéria/ Soldado Medeiros é um vulto da Bahia, é um herói de uma terra varonil e é aquele que comandou o Exército dos Periquitos. O que o samba-enredo destaca, portanto, é a virilidade, a capacidade guerreira e o heroísmo da personagem. Este é o único samba-enredo a associar a personagem ao masculino e à masculinidade, uma vez que, como veremos, com o passar dos anos, há cada vez mais uma recuperação da personagem como exemplo de uma mulheridade guerreira.

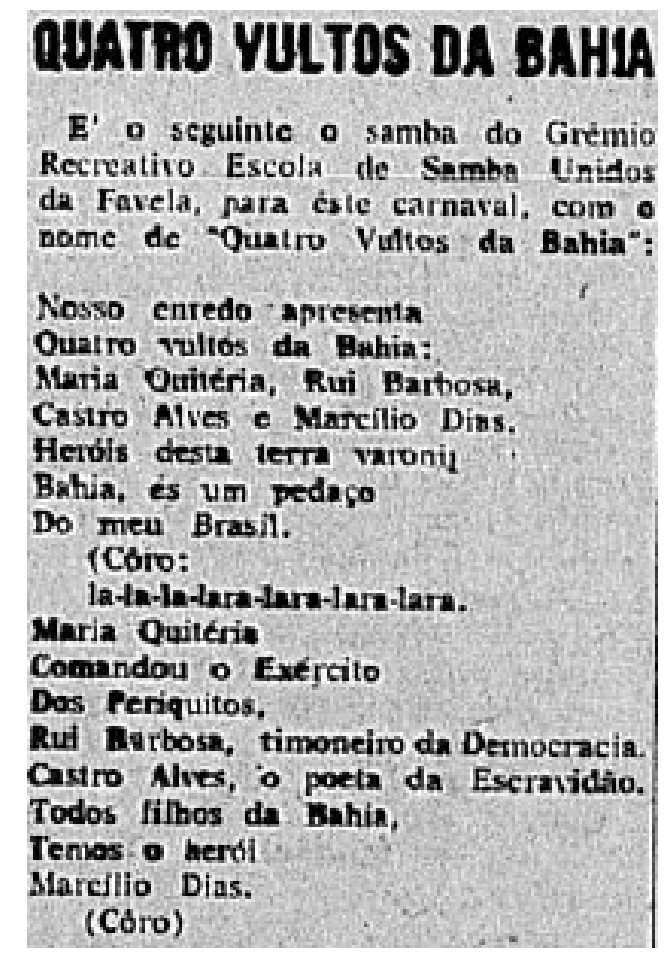

Imagem 1 - Letra do samba-enredo Quatro vultos da Bahia.

Fonte: Diário Carioca, 5 de fevereiro de 1959, p. 11. 
A Escola de Samba, no entanto, comete dois erros históricos importantes. Nem o marinheiro negro Marcílio Dias é baiano, nem Maria Quitéria comandou o Batalhão dos Periquitos. Sobre Marcilio Dias, o Diário Carioca, de 7 de fevereiro de 1959, página 11, ironiza o erro da Escola, que canta que o gaúcho Marcilio Dias era baiano, na sugestiva coluna "Quem sabe, sabe!", assinada por Barrigudo. No que se refere a nossa personagem, o Batalhão dos Periquitos foi comandado, em verdade, pelo avô do poeta Castro Alves, o major José Antônio da Silva Castro, que não só soube da transição de gênero do Soldado Medeiros durante a guerra, como também permitiu que Maria Quitéria, agora entendida unicamente como mulher, seguisse sob seu comando, inclusive sob protestos de seu pai e da proibição da participação feminina no exército brasileiro. ${ }^{6}$

Cinco anos depois, a multicampeã do carnaval niteroiense, a Unidos do Viradouro, cruza pela primeira vez a Baía de Guanabara, deixando para trás, por alguns anos, os desfiles da Avenida Amaral Peixoto, para desfilar na cidade do Rio de Janeiro. No dia 10 de fevereiro, segunda de carnaval, na Praça XI, às 20 horas, começam a desfilar as mais de vinte e oito Escolas da terceira divisão do carnaval carioca. Os jornais relatam que naquele ano os desfiles da terceira divisão duraram mais de quinze horas. ${ }^{7}$ É provável, portanto, que a Viradouro, tendo sido a vigésima segunda Escola a se apresentar, com aproximadamente mil integrantes, ${ }^{8}$ tenha feito a sua estreia no carnaval carioca, com o samba-enredo Maria Quitéria, somente na manhã do dia 11 de fevereiro, terça de carnaval.

Talvez, por isso, apesar do favoritismo, ${ }^{9}$ não tenha ficado registrado nem mesmo a colocação final da Escola azul e rosa de Niterói. ${ }^{10}$ Naquele ano, entre as vinte oito Escolas, só sabemos a posição das doze primeiras. Infelizmente não foi somente a colocação final da Escola que os jornais não registraram, visto que, apesar de intensa busca, não conseguimos localizar nem mesmo a letra do samba-enredo Maria Quitéria, e, por isso, nada mais podemos afirmar sobre a personagem. Neste mesmo ano, no entanto, a Unidos do Cabuçu, de quem falaremos no próximo ponto, desfilava na primeira divisão do carnaval carioca, o samba-enredo Brasil de norte a sul, que abordava indiretamente Maria Quitéria/Soldado Medeiros.

Cinco anos depois, em 16 de fevereiro de 1969, domingo de carnaval, Maria Quitéria/Soldado Medeiros retorna à Praça XI, com os mais de setecentos integrantes da Unidos de Bangu, ${ }^{11}$ divididos em dez alas, através do samba-enredo Maria Quitéria, heroína da independência. Depois de quatro horas de atraso, dezoito Escolas desfilaram na terceira divisão do carnaval carioca. ${ }^{12} \mathrm{~A}$ Unidos de Bangu, do carnavalesco Josafá Pereira, foi a sétima Escola a desfilar, provavelmente na madrugada do dia 17, e terminou na décima quarta colocação. Apesar da posição final, os mais de cinquenta ritmistas, da bateria da Escola, receberam demorados aplausos. ${ }^{13}$

Infelizmente, no entanto, assim como aconteceu com a Unidos de Viradouro, não conseguimos localizar nenhuma outra informação, nem mesmo a letra do samba-enredo de autoria de Cidenir Matos. Nesse sentido, a única coisa que podemos inferir, por conta do subtítulo do samba-enredo, é que a personagem continuou a ser lida através da sua participação nas lutas de independência do Brasil.

Vinte e três anos depois de seu primeiro carnaval sobre Maria Quitéria/Soldado Medeiros, 
a Caprichosos de Pilares volta a cantar, com o samba-enredo Vida e Glória de Maria Quitéria, heroína de uma raça, na segunda de carnaval, dia 21 de fevereiro, na terceira divisão, na Avenida Rio Branco, a vida da nossa personagem. Apesar dos trinta e cinco minutos de atraso, a Escola foi a primeira, entre outras quatorze agremiações, a desfilar. Sob aplausos, ${ }^{14}$ com seus 1500 componentes, 105 ritmistas, 32 alas, 10 destaques e 4 carros alegóricos, a Caprichosos terminou na terceira colocação, e subiu no ano seguinte para a segunda divisão do carnaval. ${ }^{15}$

Apesar de termos localizado apenas a letra do samba-enredo, de Alcino Correia, o Ratinho, convém destacar uma longa nota publicada no jornal Luta Democrática, de 26 de janeiro de 1977, que não só ressalta as pretensões da Escola de voltar às primeiras divisões do carnaval carioca, mas também faz uma longa apresentação sobre Maria Quitéria/Soldado Medeiros. Ainda que esta nota não seja assinada, nem pela Escola nem por qualquer outra pessoa, é muito provável que tenha sido escrita a partir de informações fornecidas pela Caprichosos de Pilares. Nesse sentido, é muito provável também que o carnaval, e seus carros e alegorias, tenha refletido o conteúdo publicado pelo jornal. Esta hipótese se confirma com a letra do samba-enredo, que repete a maior parte das informações da notícia.

Assim sendo, o texto aponta duas motivações para a transição de gênero e para a ida à guerra de Maria Quitéria/Soldado Medeiros: a primeira diz respeito à insatisfação com a vida que levava, seja porque desejava casar com alguém que o pai não autorizava, seja porque desejava desempenhar atividades que eram proibidas às mulheres, enquanto a segunda diz respeito ao desejo de lutar pela independência do Brasil. É importante frisar que não é a insatisfação com o patriarcado que leva ao desejo da guerra, mas são duas motivações independentes. Nesse sentido, a guerra e a transição de gênero são possibilidades de fugir do sistema patriarcal, mas também de realizar o seu sonho guerreiro.

A nota jornalística não esconde que a personagem viveu como homem, sob o nome de "Soldado Medeiros", assim como também não explica a transição de gênero como um "disfarce", como acontecia na maior parte dos textos históricos e literários daquele momento. ${ }^{16}$ Apesar disso, afirma que o soldado, com o fim da guerra, "volta" a viver como uma mulher, ainda que siga desobedecendo os limites do que deveria ser uma mulher. O samba-enredo de Ratinho, ainda que fale explicitamente em disfarce, não deixa, entretanto, de destacar a vida como homem e soldado. Assim como também destaca que ao "voltar" a viver como mulher, nunca esteve completamente subordinada à ordem paterna.

O samba também canta a personagem como uma "heroína da independência", que combateu com seu fuzil não só pela liberdade brasileira, mas também pela sua própria liberdade, e sugere que o carnaval da Caprichosos reencenará as batalhas enfrentadas por Maria Quitéria/ Soldado Medeiros, as quais dizem respeito tanto às suas escolhas afetivas quanto à independência brasileira. Ademais, o samba canta também que foi condecorada pelo Imperador e foi perdoada pelo pai. Isto posto, apesar de entender a transição de gênero como parte da complexa mulheridade da personagem, ao cantá-la e encená-la, a Caprichosos possibilita aos leitores e foliões compreendê-la de outra forma.

Infelizmente, portanto, como pudemos ver, entre os cinco sambas que abordam direta- 
mente Maria Quitéria/Soldado Medeiros, temos apenas a letra dos sambas-enredos de duas dessas Escolas, da Unidos da Favela, de 1959, e da Caprichosos de Pilares, de 1977. Apesar do escasso material, podemos dizer que as duas Escolas não apagam a masculinidade e a vida como homem e soldado experimentados pela personagem. Nesse sentido, a Unidos faz isso quando associa a personagem a outras figuras masculinas importantes da "Bahia", enquanto a Caprichosos, apesar de falar em disfarce, canta o heroísmo do Soldado Medeiros. Essa leitura carnavalesca, diferentemente da narrativa histórica e literária do momento, se não propõe uma perspectiva menos normativa sobre gênero, ao menos favorece leituras nesse sentido.

\section{Agora chegou a vez vou cantar: Bahia, berço do Brasil}

Ao contrário dos carnavais em que Maria Quitéria/Soldado Medeiros é protagonista, em que encontramos pouco material de pesquisa, em todos os carnavais em que a personagem aparece de forma indireta encontramos pelo menos a letra do samba-enredo. Neste ponto, portanto, analisaremos sete carnavais, sendo o primeiro de 1964, da Unidos do Cabuçu, e o último de 2020, da Império Serrano. É importante destacar que a Unidos do Cabuçu realizou três carnavais onde Maria Quitéria/Soldado Medeiros figurou de forma secundária, enquanto a Império Serrano realizou outros dois. Nesse sentido, analisaremos sete carnavais de apenas quatro Escolas de samba.

Enquanto os carnavais diretos, como vimos, foram encenados na segunda e na terceira divisão do carnaval carioca, os carnavais indiretos se apresentaram na primeira e na segunda divisão. Maria Quitéria/Soldado Medeiros, portanto, só aparece no palco principal do carnaval carioca quando narrada de modo indireto. Os dois principais temas dos carnavais indiretos são as mulheres brasileiras, o que indica que a personagem é encenada a partir da reafirmação de sua mulheridade, e a Bahia, onde a personagem aparece como um dos símbolos do estado. Enquanto isso, nos carnavais diretos, o principal tema é a participação de Maria Quitéria/Soldado Medeiros nas guerras de independência.

Além disso, nos carnavais diretos, as melhores colocações foram da Caprichosos de Pilares, em 1954, que ficou em segundo lugar na segunda divisão e subiu no ano seguinte para a primeira divisão, e em 1977, que ficou em terceiro lugar na terceira divisão e subiu no ano seguinte para a segunda divisão, enquanto as outras Escolas permaneceram na divisão em que estavam. Nos carnavais indiretos, a melhor colocação foi da Império Serrano, em 1966, que ficou em terceiro lugar na primeira divisão. Houve, no entanto, três rebaixamentos, todos da Unidos do Cabuçu, que caiu da primeira divisão em 1964 e da segunda divisão em 1968 e 1997, enquanto as outras Escolas se mantiveram nas respectivas divisões em que estavam. Nesse sentido, podemos dizer que a presença de Maria Quitéria/Soldado Medeiros costuma favorecer a Caprichosos de Pilares, na mesma medida em que costuma desfavorecer a Unidos do Cabuçu.

No mesmo ano em que a niteroiense Unidos do Viradouro estreava no carnaval carioca, e no mesmo dia em que desfilava o samba-enredo Maria Quitéria na terceira divisão, a Unidos do Cabuçu desfilava o samba-enredo Brasil de norte a sul, na primeira divisão do carnaval carioca, abordando também a nossa personagem. Apesar de o desfile ter começado na noite do domingo 
de carnaval, dia 9 de fevereiro, a Cabuçu, que foi a penúltima Escola a desfilar, só entrou na avenida no dia seguinte, sob forte sol. De acordo com Marcos de Castro, a Cabuçu foi prejudicada não só pela demora para começar o desfile, mas principalmente pelo samba-enredo, que era muito semelhante, e inferior, ao da Império Serrano. ${ }^{17}$ A Escola prometia 1500 componentes, ${ }^{18}$ mas terminou desfilando com 800 , divididos em vinte e três alas. ${ }^{19}$

O carnaval da Cabuçu foi marcado por grandes problemas, como a perda da sua quadra de ensaios recém-reformada e o consequente rebaixamento, mas também por acertos, como o elogiado casal de mestre-sala e porta-bandeira, Cristóvão e Ceci, ${ }^{20}$ e a ala de passistas do Clube do Otimismo que sambou em suas cadeiras de roda. ${ }^{21}$ Apesar dos muitos elogios aos passistas cadeirantes, e da calorosa recepção do público, houve também quem afirmasse que esta ala foi a "ideia mais triste" do carnaval daquele ano. ${ }^{22}$ Com o resultado final, muitas Escolas contestaram a classificação, sob a alegação de que houve troca não informada da Comissão julgadora, além da quebra do sigilo dos resultados. Apesar da repercussão na imprensa, o resultado foi mantido.

O samba-enredo, de autoria de Iba Nunes, Jorival de Moraes e Maciel Lopes, afirma que o Brasil, de norte a sul, é um "celeiro divinal" e "suntuoso", e destaca aspectos da cultura e da geografia brasileiras que confirmam essa perspectiva. Nesse sentido, fala-se das florestas primorosas do Norte, do maracatu e do frevo pernambucano, dos parques industriais paulistanos, dos carnavais cariocas, do ouro e das pedras preciosas mineiras, da uva e do churrasco gaúcho, do planalto e do progresso da capital federal, etc. A Bahia sobressai nos elogios, destacando-se a capoeira, o candomblé, a beleza da Praça da Sé, o vatapá, o acarajé e Maria Quitéria, única pessoa nomeada em todo o samba-enredo.

Apesar de serem apenas dois versos sobre a nossa personagem, podemos inferir que Maria Quitéria é entendida como um símbolo representativo não só da Bahia, mas das mulheres baianas e das mulheres corajosas. Nesse sentido, não há nenhuma menção nem à transição de gênero vivida pela personagem nem ao nome masculino sob o qual combateu nas guerras de independência, sendo desse modo entendida exclusivamente como uma mulher (cisgênera). Apesar disso, Maria Quitéria não é celebrada a partir de sua mulheridade, mas a partir de sua glória e de sua coragem. Nesse sentido, o feminino que a Cabuçu celebra não está reduzido a uma visão heteronormativa e patriarcal da mulher.

Dois anos depois, em 1966, a Império Serrano, na primeira divisão do carnaval, aborda novamente a personagem a partir de um enredo centrado não no Brasil, mas na Bahia. $\mathrm{O}$ samba-enredo Glória e graças da Bahia, ${ }^{23}$ de Silas de Oliveira e Joacyr Santana, interpretado por Abílio Martins, destaca as glórias e os costumes da "formosa" Bahia. Nesse sentido, a Escola canta as catedrais, o candomblé e Iemanjá, as baianas e a festa do Senhor do Bonfim, as comidas, como o caruru, o vatapá e o acarajé, além dos seus heróis de "bravura varonil", "grandes vultos" da história brasileira. Novamente, assim como no samba-enredo da Unidos da Favela, de 1959, são destacadas quatro figuras históricas: Maria Quitéria, "a brava heroína", Ana Neri, "símbolo de abnegação", Castro Alves, "apóstolo da abolição", e Rui Barbosa, "gênio da civilização". 
A Império Serrano foi a oitava Escola a desfilar na passarela da Avenida Presidente Vargas, tendo se apresentado no começo da tarde da segunda-feira de carnaval, sendo que o desfile começou às $23 \mathrm{~h}$ do dia anterior e durou mais de quinze horas. ${ }^{24}$ Apesar disso, a Império foi unanimemente apontada pelos jornais cariocas como uma das grandes favoritas, juntamente com a Mangueira, ${ }^{25}$ tendo como ponto forte principal o seu samba-enredo. De acordo com um texto que circulou com pequenas variações em vários jornais cariocas, provavelmente produzido pela própria Escola, o carnaval da Império se dividia em três partes. Na primeira, destacava-se a fundação da cidade de Salvador até a transferência da capital para o Rio de Janeiro; na segunda, destacava-se as festas populares, as feiras, a capoeira e o candomblé; na terceira e última, dois heróis - Castro Alves e Rui Barbosa - e duas heroínas - Maria Quitéria e Ana Neri. ${ }^{26}$

De modo similar ao carnaval da Unidos do Cabuçu, de 1964, o grande destaque do samba-enredo é a Bahia, sendo Maria Quitéria narrada, em apenas um verso, como um vulto da história brasileira e uma brava heroína baiana. Não há, dessa forma, qualquer menção nem à transição de gênero vivida pela personagem nem ao nome masculino sob o qual combateu nas guerras de independência, sendo, portanto, entendida exclusivamente como uma mulher (cisgênera). Apesar disso, assim como na Unidos do Cabuçu, a personagem não está reduzida a uma visão limitada, heteronormativa e patriarcal de mulheridade, ao contrário, Maria Quitéria garante o seu lugar na história brasileira e baiana, assim como no samba-enredo da Escola, a partir tanto de sua "bravura varonil" como de sua mulheridade.

Dois anos depois, em 1968, pela segunda vez, a Unidos do Cabuçu volta a abordar Maria Quitéria/Soldado Medeiros. No entanto, enquanto no carnaval de 1964, apesar do destaque dado à Bahia, o samba-enredo falava de Brasil, no carnaval de 1968 o samba-enredo A primazia da Bahia se volta exclusivamente à Bahia. O desfile marcado para começar às 20h, no domingo de carnaval, dia 25 de fevereiro, começa, no entanto, às 21:30, sob forte chuva. ${ }^{27} \mathrm{~A}$ Unidos foi a quarta Escola a desfilar na Avenida Rio Branco, na segunda divisão, e terminou em último lugar, sendo novamente rebaixada.

O samba-enredo, de autoria desconhecida, destaca o "passado exuberante" e as "primazias fascinantes" da Bahia, e narra a chegada dos portugueses e a realização da primeira missa no Brasil, a fundação de Salvador, o encontro de Catarina Paraguaçu e Caramuru, o nascimento da medicina brasileira e Maria Quitéria. Os dois versos do carnaval de 1964, que destacavam a glória e a coragem da personagem, se transformam em cinco versos no carnaval de 1968, que destacam o heroísmo e o recebimento da condecoração da Ordem Imperial do Cruzeiro do Sul. Assim como no carnaval de 64, não há menção nem à transição de gênero nem ao nome masculino sob o qual combateu, sendo novamente explícita e unicamente narrada como uma mulher (cisgênera), ainda que seja mais celebrada por suas ações heroicas do que por uma visão limitada e heteronormativa de mulheridade.

Quatro anos depois, em 13 de fevereiro de 1972, domingo de carnaval, na primeira divisão, a Bahia e Maria Quitéria voltam ao palco principal do carnaval com a Em cima da hora e o samba-enredo Bahia, berço do Brasil. A Escola de Cavalcante foi a quarta a desfilar, e estava pela 
segunda vez na primeira divisão do carnaval, por isso as pretensões eram apenas permanecer na mesma divisão. ${ }^{28} \mathrm{O}$ objetivo foi alcançado com o oitavo lugar; apesar disso, o resultado foi considerado injusto, uma vez que os críticos apontavam pelo menos um quinto lugar. ${ }^{29}$ O ponto alto da Escola, no entanto, foi sem dúvida o samba-enredo de Baianinho ${ }^{30}$ e a bateria de Mestre Ivo, que neste ano incorporava instrumentos do candomblé, como atabaques. ${ }^{31} \mathrm{~A}$ Escola também distribuiu, durante o desfile, cerca de vinte mil souvenirs, especialmente figas, patuás e cordões, que foram ofertados pela Bahiatursa, órgão estadual de fomento ao turismo. ${ }^{32}$

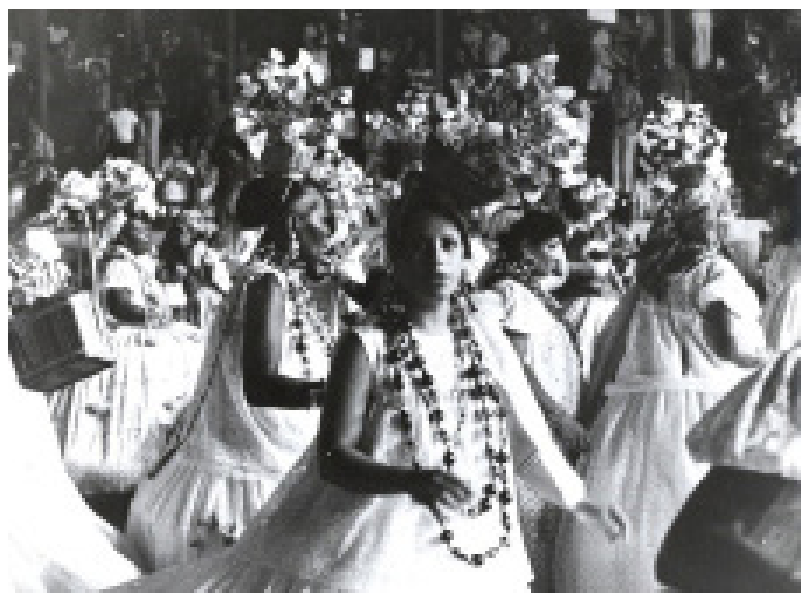

Imagem 2 - Desfile da Em cima da hora em 1972.

Fonte: Correio da Manhã, de 14 fevereiro de 1972.

Sobre a nossa personagem, cabe destacar que a bateria, composta por aproximadamente duzentos ritmistas, vestiu a farda do Batalhão dos Periquitos, ${ }^{33}$ pelo qual lutou Maria Quitéria/ Soldado Medeiros nas guerras de independência. Além disso, a personagem foi também destaque da Escola, onde ganhou vida através de Valdemira. ${ }^{34}$ Infelizmente não conseguimos imagens dessas duas alas. O samba-enredo Bahia, berço do Brasil ${ }^{35}$ fala principalmente da Lavagem do Bonfim e da Igreja de São Francisco, do Candomblé e Iemanjá, da pesca e da capoeira, e de Maria Quitéria. Apesar do release, provavelmente distribuído à imprensa pela assessoria, ${ }^{36}$ onde se fala de sua vida como soldado e de seu nome masculino, ${ }^{37}$ os cinco versos do samba-enredo a cantam exclusivamente como uma mulher (cisgênera), e apagam qualquer informação sobre transição de gênero. Nesse sentido, Maria Quitéria é destacada pela sua heroicidade, por ser uma "mulher de grande valor" e por ter lutado não só pela liberdade, mas também contra um "terrível preconceito".

Não é possível inferir a que preconceito o samba-enredo se refere, mas é provável que fale antes da proibição da participação feminina no exército brasileiro do que de uma referência ao seu gênero e à sua vida como homem e soldado. Apesar disso, assim como os outros sambas-enredos indiretos, é possível dizer que o que as Escolas celebram na personagem é antes de 
tudo as rupturas às normatividades de gênero. Nesse sentido, enquanto nos sambas-enredos diretos essas rupturas são justificadas pela luta em nome da pátria, nos sambas enredos indiretos a luta pela pátria vai se tornando cada vez mais uma luta pela liberdade de forma geral, o que passa a incluir a liberdade em relação às normas de gênero. O carnaval da Em cima da hora, portanto, parece apontar para uma virada narrativa sobre a personagem, cujo ápice é o carnaval da Império Serrano, de 2020, sobre o qual falaremos mais adiante.

Aquilo que em 1972 parece ser o início de uma virada narrativa sobre Maria Quitéria/ Soldado Medeiros, com o carnaval da Em cima da hora, onde a personagem se torna cada vez mais sinônimo de liberdade às normatividades de gênero e cada vez menos sinônimo das lutas de independência do Brasil, vinte e cinco anos depois se confirma não só com o carnaval da Unidos do Cabuçu, de 1997, mas também com os carnavais da Mangueira, de 2015, e da Império Serrano, de 2020. Essa mudança narrativa pode ser inferida inclusive através dos títulos dos sambas-enredos, que começam por ressaltar as mulheres de forma geral, como Todas as Marias da nossa terra, da Unidos do Cabuçu, e termina com a reafirmação do slogan feminista Lugar de mulher é onde ela quiser!, da Império Serrano.

No dia 16 de fevereiro de 1997, domingo de carnaval, na segunda divisão, a Unidos do Cabuçu aborda pela terceira vez Maria Quitéria/Soldado Medeiros. Enquanto nos carnavais de 1964 e 1968, a personagem é narrada como um símbolo da glória, da coragem e do heroísmo do Brasil e da Bahia, no carnaval de 1997, Maria Quitéria/Soldado Medeiros, sem deixar de ser a "heroína da libertação", é cantada como parte das mulheres heroicas do Brasil. Nesse sentido, o samba-enredo Todas as Marias da nossa terra, ${ }^{38}$ de Ney do Cabuçu, Carlos Werneck, Jadir, Sérgio Magnata, Beto Pernada e Di Miguel, interpretado por Celsinho, faz uma "exaltação" de mulheres brasileiras cujo nome começa com Maria, como Maria Esther, campeã mundial de tênis, Maria Leopoldina, imperatriz brasileira, Maria Bonita, cangaceira do bando de Lampião, Maria das Graças/Gal Costa e Maria Bethânia, cantoras, e Maria Quitéria, "heroína da libertação".

Entendida a partir de sua mulheridade, e da mulheridade das outras personagens, o samba-enredo não faz qualquer menção à transição de gênero vivida pela personagem, assim como também não faz qualquer menção ao seu nome masculino. Na passarela do samba, entre os três mil componentes, a personagem aparece em uma pequena ala que remete ao Batalhão dos Periquitos. ${ }^{39}$ Nesse sentido, a ideia da "heroína da libertação" do samba-enredo faz referência tanto à libertação feminina quanto à libertação nacional. No entanto, assim como nos outros carnavais, a Unidos do Cabuçu terminou em sétimo lugar e, por isso, foi rebaixada para a terceira divisão.

Quase vinte anos depois, no dia 15 de fevereiro de 2015, Maria Quitéria/Soldado Medeiros volta ao palco principal do carnaval carioca, com o samba-enredo Agora chegou a vez vou cantar: mulher de Mangueira, mulher brasileira em primeiro lugar! $4^{40}$ Apesar de não estar explicitamente citada no samba-enredo, podemos dizer que os versos "Glória a essas divas tão guerreiras / a nossa Maria não é brincadeira / É raça, é fibra, é jequitibá" são uma forma de marcar a sua presença na letra do samba. Assim sendo, Maria Quitéria/Soldado Medeiros seria ao mesmo 
tempo uma diva e uma guerreira. Entendendo-a, portanto, unicamente como uma mulher-diva-guerreira, não há espaço no samba-enredo para qualquer informação sobre a transição de gênero ou sobre o seu nome de soldado.

Ainda que a referência não seja tão explícita no samba-enredo de Renan Brandão, Cadu, Alemão do Cavaco, Paulinho Bandolim, Deivid Domênico e Almy, a nossa personagem, no entanto, aparece não só na Sinopse do Enredo, ${ }^{41}$ produzida pelo carnavalesco Cid Carvalho, para ser distribuída à imprensa, mas também ganha corpo na ala vinte e sete, que representa Maria Quitéria/Soldado Medeiros com o fardamento do Batalhão dos Periquitos.42 Na Sinopse, o carnavalesco destaca "mulheres que se colocaram à frente de seus tempos", incluindo não só as mulheres mangueirenses, como Vovó Lucíola, Tia Fé, Suluca, Tia Lina, Neide, Mocinha, Dona Zica, como também "outras grandes mulheres do Brasil", como Xica da Silva, Tia Ciata, Mãe Menininha, Tarsila do Amaral, Rachel de Queiroz, Rita Lee, Maria da Penha, Fernanda Montenegro, e divindades do candomblé, como Oxum. O desfile pretende valorizar e reconhecer aquilo que "a história oficial muitas vezes lhes negou".

Maria Quitéria/Soldado Medeiros, na Sinopse, aparece associada a uma mulher mangueirense, a Dona Neuma. Nesse sentido, Neuma se faz de Maria Quitéria, quando precisa "defender o samba e a Mangueira", mas também se faz de Ana Néri, quando precisa socorrer alguém. Nossa personagem, portanto, está associada à capacidade guerreira de Neuma. Sendo entendida exclusivamente como uma mulher (cisgênera), nada se fala sobre características que possam desestabilizar esse lugar. No chão da Escola, entre quase quatro mil pessoas, divididas em trinta e cinco alas, sete carros alegóricos e um tripé, Maria Quitéria/Soldado Medeiros aparece na ala vinte e sete com seu clássico uniforme do Batalhão dos Periquitos. ${ }^{43}$

No desfile também aparecem outras "mulheres guerreiras" não citadas nem no samba-enredo nem na Sinopse, como Teresa de Benguela, Agotime, Dandara, Maria Bonita etc. No desfile, portanto, Maria Quitéria é uma mulher que foi à guerra. Durante a transmissão, no entanto, a repórter e narradora do desfile, Fátima Bernardes, acrescenta uma informação que a Escola parece se negar a dar. Ainda que entenda a transição de gênero como um disfarce, Bernardes é a única a de alguma forma sugerir que a personagem viveu como homem e soldado.

Cinco anos depois, em 21 de fevereiro de 2020, sexta de carnaval, Maria Quitéria/Soldado Medeiros faz a sua última, até aqui, aparição na avenida, na segunda divisão, e pela segunda vez na Império Serrano. A Escola se apresentou com 2100 pessoas divididas em vinte e três alas, três carros alegóricos e um tripé. No entanto, enquanto no carnaval de 1966 a Escola conquistou o terceiro lugar da primeira divisão, sendo considerada uma das grandes favoritas ao título, no carnaval de 2020 a Escola enfrentou graves e constrangedores problemas e por pouco não caiu para a terceira divisão , ficando em nono lugar. Além disso, enquanto em 1966 a Escola lia Maria Quitéria/Soldado Medeiros através da história da Bahia, em 2020 a Império Serrano lê a personagem através da ideia de "empoderamento feminino". 


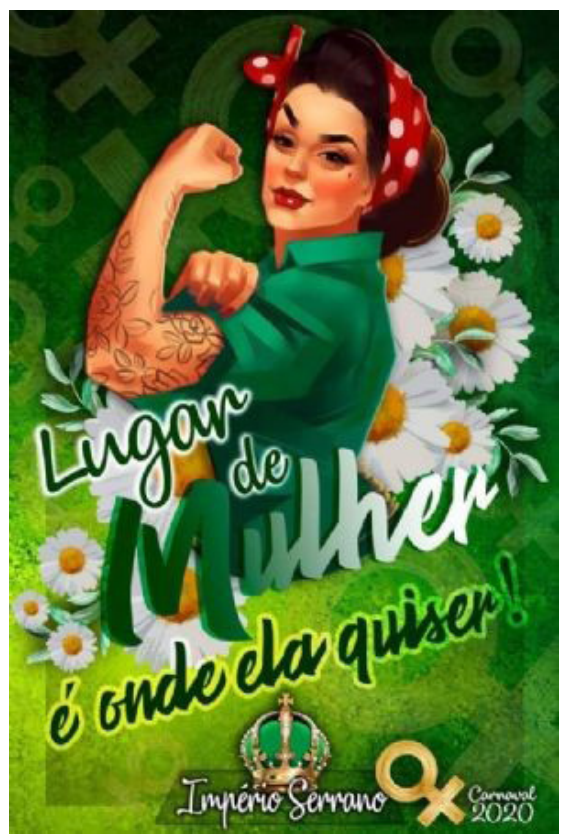

Imagem 3 - Cartaz do desfile produzido pela Império Serrano.

Fonte: <https://bityli.com/ZkVbu>. Acesso em 22 dez 2020.

Em 2020, conforme Sinopse do Enredo produzida pelo carnavalesco Júnior Pernambucano e pela pesquisadora Helenise Guimarães , a Império Serrano canta e exalta a vida de "mulheres fortes, combativas, que se destacaram em nossa história e deixaram marcas indestrutíveis". Mulheres, como diz o texto, que se fizeram ouvir e empoderaram outras mulheres, assim a "passarela momesca será transformada num verdadeiro palco das heroínas sem estátuas". 0 enredo destaca não só mulheres vinculadas à Império Serrano, como Tia Maria do Jongo, Tia Eulália, Ivone Lara e Neide Coimbra, como também outras "mulheres poderosas" brasileiras, como Clara Camarão, as "Heroínas de Tejucupapo", Joana Angélica, Maria Felipa, Anita Garibaldi, Dandara, Tereza de Benguela, Nísia Floresta, Leolinda Daltro, Bertha Lutz, Pagu, Rita Lee, Chiquinha Gonzaga, Carmem Miranda, Dercy Gonçalves, Maria Lenk, Marta Vieira, Maria Alves, Maria da Penha e Cecília Meireles.

Maria Quitéria/Soldado Medeiros não aparece explicitamente nomeada no samba Lugar de mulher é onde ela quiser!. Apesar disso, aparece, ainda que equivocadamente, na Sinopse do Enredo e no desfile, na ala A força de Maria Quitéria. Na Sinopse, fala-se, equivocadamente, de Maria Quitéria como se ela fosse uma das "heroínas de Tejucupapo", e teria, por isso, lutado contra os holandeses em Pernambuco. Dessa forma, a sinopse destaca a sua capacidade guerreira. No desfile, no entanto, a personagem aparece com o seu clássico fardamento do Batalhão dos Periquitos, ${ }^{46}$ destacando-se, portanto, a participação feminina nas lutas de independência. Não há espaço nem na Sinopse nem no desfile, assim como também não haverá no samba- 
-enredo, para qualquer tema que desestabilize a mulheridade de Maria Quitéria/Soldado Medeiros, por isso nada se fala sobre sua vida como homem e soldado. ${ }^{47}$

O samba-enredo, $4^{8}$ de Aluísio Machado, Beto BR, Lucas Donato, Luiz Henrique, Matheus Machado, Rafael Prates, Renan Diniz, Senna e Thiago Bahiano, nomeia apenas duas mulheres, Dandara e Tereza de Benguela; no entanto, canta e evoca outras "Marias guerreiras". Maria Quitéria, portanto, pode ser inferida através das ideias de "resistência", "bravura" e "valentia", que são associadas às "Marias guerreiras". Essas três características, no entanto, dizem respeito antes à sua própria mulheridade e não à sua condição de soldado nas lutas de independência. Nesse sentido, o samba-enredo cumpre aquilo que se anuncia desde o início da década de 70, com o carnaval da Em cima da hora, transformando a "heroína da independência" em um símbolo da luta pela liberdade e igualdade de gênero.

\section{Conclusões}

Enquanto tema principal de um samba-enredo, Maria Quitéria/Soldado Medeiros enfrenta um silêncio absoluto desde a década de 70, com o samba-enredo Maria Quitéria, heroína de uma raça. Ademais, houve grande dificuldade de encontrar material de análise dos sambas-enredos diretos, o que sem dúvida está associado à divisão em que as Escolas se apresentaram, na segunda e na terceira divisão, mas também ao ano do carnaval, entre as décadas de 50 e 70. Nos sambas-enredos diretos, a priori, podemos dizer que, ainda que a personagem seja entendida exclusivamente como mulher, há a informação sobre sua vida como homem e soldado, mesmo que seja entendida como "disfarce". Por fim, podemos dizer também que nestes carnavais a história da personagem ainda está muito associada às lutas pela independência do Brasil.

Enquanto tema secundário de samba-enredo, Maria Quitéria/Soldado Medeiros aparece desde a década de 60 até o último carnaval. Diferentemente dos sambas-enredos direitos, encontramos grande quantidade de material, seja na imprensa, seja fonográfico, seja audiovisual, o que sem dúvida diz respeito principalmente à divisão em que as Escolas se apresentaram, na primeira e na segunda divisão. Nos sambas-enredos indiretos, podemos dizer que há dois momentos significativamente distintos: no primeiro, a personagem aparece principalmente como um símbolo do Brasil e da Bahia, estando muito associada às lutas de independência; no segundo, a personagem aparece principalmente como símbolo feminino de luta contra as desigualdades de gênero. Nos dois casos, no entanto, não se aborda a transição de gênero vivida por Maria Quitéria/Soldado Medeiros. Nesse sentido, parece haver, a partir de uma leitura cada vez mais feminista sobre a personagem, um crescente apagamento de parte de sua história em prol de uma imagem feminista que se constrói em torno dela.

A ideia aqui não é apontar o feminismo como parte das estruturas silenciadoras sobre a personagem; ao contrário, pretendemos destacar que essa leitura é importante, mas é também equivocadamente cisgênera, uma vez que não se propõe a debater explicitamente a questão da transição de gênero, que é um traço extremamente significativo de sua história. Nesse sentido, parece-nos que os feminismos precisam ser cada vez mais transfeministas, ou correremos o risco de seguir silenciando expressões de gênero que fogem às normatividades 

como uma pessoa trans, mas, modestamente, pretendemos indicar que esse debate precisa ser feito.

\section{NOTAS}

* Helder Thiago Maia é Doutor em Literatura Comparada (UFF, 2018), realiza estágio de pós-doutoramento, com bolsa da FAPESP no. 2018-19521-4, no Programa de Pós-graduação de Estudos Comparados de Literaturas de Língua Portuguesa da Universidade de São Paulo. É pesquisador do NuCuS, da Universidade Federal da Bahia, e pesquisador associado da Red LIESS, da Espanha. É editor da Revista Periódicus (UFBA).

${ }^{1}$ Sobre as primeiras doze obras publicadas a narrarem Maria Quitéria/Soldado Medeiros, consultar Maia (2021).

${ }^{2}$ Sobre esses textos literários, consultar Maia (2021).

${ }^{3}$ Nesse sentido, podemos destacar por exemplo as obras de Joaquim Norberto Souza Silva (1862), Ignez Sabino (1899), Bernardino José Souza (1936) e Olmio Barros Vidal (1945).

${ }_{4}^{4}$ Algumas fontes indicam que o carnaval sobre Maria Quitéria/Soldado Medeiros aconteceu em 1955. No entanto, os jornais indicam que o samba-enredo da Caprichosos em 1955 foi o Retirada da Laguna. Sobre isto, ver, por exemplo, os jornais Última Hora, de 23 de fevereiro de 1955, página 4, Diário da Noite, de 23 de fevereiro de 1955, página 4, e Luta Democrática, de 12 de fevereiro de 1955 , página 2.

${ }_{5}^{5}$ Há fontes divergentes sobre a posição final da Escola; os jornais da época, no entanto, indicam que a Unidos da Favela ficou na vigésima segunda colocação. Sobre isto, ver os jornais Diário da Noite, de 13 de fevereiro de 1959, página 12, Diário de Notícias, de 13 de fevereiro de 1959, página 11, e Tribuna da Imprensa, de 13 de fevereiro de 1959, página 9.

${ }^{6}$ Em 1865, Jovita Feitosa, inspirada pela história de Maria Quitéria/Soldado Medeiros, se alistou como homem e, após ser descoberta a sua transição de gênero, foi aceita como mulher, pelo governador do Piauí Franklin Dória, no Exército Nacional, como segundo-sargento. No Rio de Janeiro, no entanto, o ministro da guerra José Antônio de Saraiva, e depois o imperador D. Pedro II, negaram a sua participação na Guerra do Paraguai, sob a alegação que a presença feminina no exército brasileiro não era permitida. Sobre a relação entre Franklin Dória, Jovita Feitosa e Maria Quitéria/Soldado Medeiros, consultar Maia (2021).

7 Ver o jornal Luta democrática, de 13 de fevereiro de 1964, p. 7.

${ }^{8}$ Ver o jornal Diário Carioca, de 24 de janeiro de 1964, p. 10.

9 Ver o jornal Diário Carioca, de 24 de janeiro de 1964, p. 10.

${ }^{10}$ Somente a partir de 1971, a Unidos do Viradouro trocou a azul e rosa, pelo branco e vermelho.

${ }^{11}$ Ver O Jornal, de 16 de fevereiro de 1969, p. 22.

${ }_{12}$ Ver Luta democrática, de 20 de fevereiro de 1969, p. 2.

${ }_{13}$ Ver Luta democrática, de 20 de fevereiro de 1969, p. 2.

${ }_{14}$ Neste carnaval, duas Escolas, da terceira divisão, foram intensamente aplaudidas, a Caprichosos de Pilares, que homenageava a "donzela-guerreira" Maria Quitéria/Soldado Medeiros, e a Unidos de Padre Miguel, que homenageava a "donzela- 


\section{Cadernos de Literatura Comparada}

Maria Quitéria/Soldado Medeiros no carnaval carioca

-guerreira" Nzinga Mbandi. Sobre Maria Quitéria/Soldado Medeiros e Nzinga Mbandi enquanto "donzelas-guerreiras", consultar Maia (2018). Os ritmistas das duas Escolas foram ovacionados. No entanto, durante o desfile de Nzinga, contagiados pela vibração e pela história da Rainha angolana negra, os foliões invadiram a pista para dançar junto com a Escola. Sobre isto, ver o jornal Tribuna da Imprensa, de 23 de fevereiro de 1977, p. 7.

15 Sobre a composição da Escola, ver o jornal Luta Democrática, de 26 de janeiro de 1977, p. 5.

${ }^{16}$ Sobre isto, ver Maia (2021).

${ }_{17}$ Ver Jornal do Brasil, de 13 de fevereiro de 1964, p.17.

${ }^{18}$ Ver Luta Democrática, de 26 de janeiro de 1964, p. 9.

${ }_{19}$ Ver <https://bityli.com/guoMp>. Acesso em $16 \mathrm{dez} 2020$.

${ }^{20}$ Ver O Jornal, de 13 de fevereiro de 1964, p. 16.

${ }^{21}$ Ver Correio da Manhã, de 13 de fevereiro de 1964, p. 5.

22 Ver Jornal do Brasil, de 13 de fevereiro de 1964, p. 17.

${ }_{23}$ Para ouvir o samba-enredo, ver <https://bit.ly/2WkoKH1>. Acesso em 16 dez 2020.

${ }^{24}$ Ver Diário de Notícias, de 24 de fevereiro de 1966, p. 5.

${ }_{25}$ Ver, por exemplo, Diário de Notícias, de 24 de fevereiro de 1966, p. 5, Correio da Manhã, de 24 de fevereiro de 1966, p. 3, e Jornal do Brasil, de 24 de fevereiro de 1966, p. 5.

${ }^{26}$ Ver Jornal do Brasil, de 17 de fevereiro de 1966, p. 28

27 Ver Suplemento de Carnaval, de 29 de fevereiro de 1968, p. 2.

${ }^{28}$ Ver Jornal do Brasil, de 25 de janeiro de 1972, p.5.

29 Ver Jornal do Brasil, de 17 de fevereiro de 1972, p.49, e de 19 de fevereiro, p.13.

${ }^{30}$ Ver Jornal dos Sports, de 3 de janeiro de 1972, p.6.

${ }^{31}$ Ver O Jornal, de 15 de janeiro de 1972, p.24, e Jornal do Brasil, de 28 de janeiro de 1972, p.13.

${ }^{32}$ Ver Jornal dos Sports, de 3 de janeiro de 1972, p.6.

33 Ver Jornal do Brasil, de 25 de janeiro de 1972, p.5.

34 Ver O Jornal, de 15 de janeiro de 1972, p.24.

35 Para ouvir o samba-enredo, acesse <https://bit.ly/2JoRcui>. Acesso em 18 dez 2020.

${ }^{36}$ Ver Jornal do Brasil, de 25 de janeiro de 1972, p.5.

37 Ver O Jornal, de 15 de janeiro de 1972, p.24.

${ }^{38}$ Para ouvir o samba-enredo, ver <https://bityli.com/snVhd>. Acesso em $21 \mathrm{dez} 2020$.

39 Para ver a ala do Batalhão dos Periquitos, assistir a partir dos sete minutos $<$ https://bityli.com/hNSK5 $>$. Acesso em 21 $\operatorname{dez} 2020$

$4^{0}$ Para ouvir o samba-enredo, ver <https://bityli.com/8elXm>. Acesso em 21 dez 2020.

${ }^{41}$ Para ver a Sinopse, consultar <https://bityli.com/2HaWG>. Acesso em 21 dez 2020.

${ }_{42}$ Para ver o desfile da Escola, consultar <https://bityli.com/D5vdM>. Acesso em 21 dez 2020.

${ }_{43}$ Para ver o Batalhão dos Periquitos, consultar, a partir de uma hora e cinco minutos: <https://bityli.com/D5vdM >. Acesso em 21 dez 2020.

44 Sobre isto, consultar <https://bityli.com/O3vI5>. Acesso em 22 dez 2020.

45 Para ler a Sinopse do Enredo, ver <https://bityli.com/ZkVbu>. Acesso em 22 dez 2020.

46 Para ver o desfile, ver <https://bityli.com/OgkAE>. A passagem do Batalhão dos Periquitos na avenida pode ser vista a partir dos vinte e um minutos. 


\footnotetext{
${ }^{47}$ É provável que haja um desconhecimento por parte dos autores do enredo sobre a transição de gênero vivida pela personagem. Afinal, a Escola desfilou com mulheres trans na avenida, como Nany People, o que indica que a transição de gênero e as mulheridades trans são também exaltadas pela Escola.

$4^{8}$ Para ouvir o samba-enredo, ver <https://bityli.com/6fwNl>. Acesso em 22 dez 2020.
}

\section{Bibliografia}

Alves, Fernando (1952), Biografia de Maria Quitéria de Jesús, Salvador, Progresso.

Barros Vidal, Olmio (1945), Precursoras brasileiras, Rio de Janeiro, A Noite.

Batista da Silva, César (2007), Relações institucionais das Escolas de Samba, discurso nacionalista e o samba enredo no regime militar - 1968-1985, dissertação de mestrado, Universidade Federal do Rio de Janeiro.

Caprichosos de Pilares (1954), Maria Quitéria, <https://bit.ly/36xiX7l> (último acesso em 04/12/2020).

Caprichosos de Pilares (1977), Maria Quitéria, heroína de uma raça, <https://bit.ly/33gVW6A> (último acesso em 04/12/2020).

Carvalho, Nancy Navarro (1958), Maria Quitéria: peça em três atos, Rio de Janeiro, Jornal do Brasil. Em cima da hora (1972), Bahia, berço do Brasil, <https://bit.ly/36izKdV> (último acesso em 04/12/2020).

Graham, Maria (1990), Diário de uma viagem ao Brasil, São Paulo, USP.

Império Serrano (1966), Glória e graças da Bahia, <https://bit.ly/3jiteHY> (último acesso em 04/12/2020).

Império Serrano (2020), Lugar de mulher é onde ela quiser!, <https://bit.ly/3ipu18R> (último acesso em 04/12/2020).

Maia, Helder Thiago (2018), "Transgressões canônicas: queerizando as donzelas-guerreiras", Cadernos de Literatura Comparada, n. 39, 91-108.

-- (2021), Maria Quitéria/Soldado Medeiros: uma soldado entre as condecorações militares e o esquecimento. No prelo.

Mangueira (2015), "Agora chegou a vez vou cantar: mulher de Mangueira, mulher brasileira em primeiro lugar!", <https://bit.ly/3jkGgEL> (último acesso em 04/12/2020).

Maria Quitéria: honra e glória (2020), <https://bit.ly/2VMoCwC> (último acesso em 04/12/2020). Reis Júnior, Pereira (1953), Maria Quitéria, Rio de Janeiro, Imprensa Nacional.

Sabino, Ignez (1899), Mulheres Illustres do Brazil, Rio de Janeiro, Garnier.

Souza, Bernardino José (1936), Heroinas Bahianas, Rio de Janeiro, José Olímpio.

Souza Silva, Joaquim Norberto (2004), Brasileiras Célebres, Brasília, Senado Federal.

Titara, Ladislau dos Santos (1837), Paraguassú: epopéia da guerra da independência da Bahia, Bahia, Typografia do Diario. 
Unidos de Bangu (1969), Maria Quitéria, heroína da independência, <https://bit.ly/349vGdm> (último acesso em 04/12/2020).

Unidos do Cabuçu (1964), Brasil de norte a sul, <https://bit.ly/3cJB6zw> (último acesso em 04/12/2020).

Unidos do Cabuçu (1968), A primazia da Bahia, <https://bit.ly/3jibOvo> (último acesso em 04/12/2020).

Unidos do Cabuçu (1997), Todas as Marias de nossa terra, <https://bit.ly/33gvSbt> (último acesso em 04/12/2020).

Unidos da Favela (1959), Quatro vultos da Bahia, <https://bit.ly/316m8H7> (último acesso em 04/12/2020).

Unidos do Viradouro (1964), Maria Quitéria, <https://bit.ly/2GdvP7x> (último acesso em 04/12/2020). 